\title{
Granulomatous Periorificial Dermatitis in an Adult A case report with review of literature
}

"Al-Mutasim Al-Qassabi, ${ }^{1}$ Khalid Al-Busaidi, ${ }^{2}$ Kaouthar Al Baccouche, ${ }^{3}$ Abla Al Ismaili ${ }^{4}$

$$
\text { التهاب الجلد الورمي الحبيبي حول الفم في شخص بالغ مراجعة }
$$

المعتصم القصابي، خالد البوسعيدي، كوثر البكوش، عبلة الإسماعيلية

ABSTRACT: Granulomatous periorificial dermatitis (GPD) is a benign, self-limiting eruption that is considered a clinical variant of periorificial dermatitis, also known as perioral dermatitis. It presents primarily in prepubertal children as monomorphic scaly papules over perioral, paranasal and periorbital areas of the face with rare occurrence in adults. We report a 36-year-old Omani male patient who presented to the Dermatology Clinic at Bahla Polyclinic, Bahla, Oman, in 2018 with a papular eruption over his face for the previous six months. Based on clinical and histopathological findings the patient was diagnosed with GPD with sarcoid-like histology. He was treated effectively with oral doxycycline and topical metronidazole. This report provides a review of the literature on GPD and summarises all reported cases in adults to date.

Keywords: Perioral Dermatitis; Dermatitis; Granulomas; Case Report; Oman.

الملخص: التهاب الجلد الورمي الحبيبي حول الفوهـة هو مرض حميد يشفى تلقائيا ويعتبر أحد الأشكال السريرية لداء التهاب الجلد حول

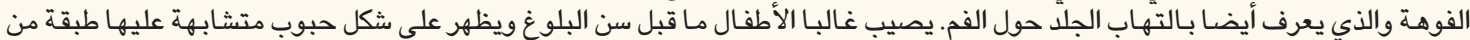

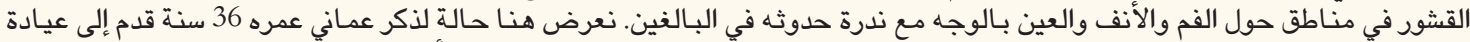

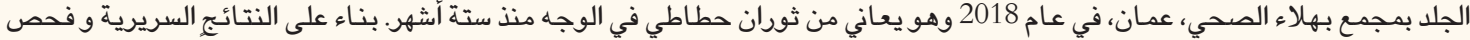

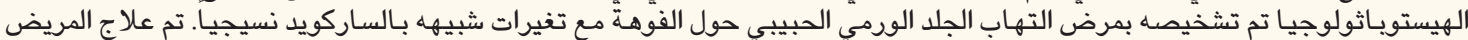

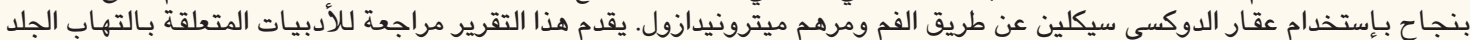
الورمي الحبيبي حول الفوهـة ويلّيص جميح الحسالات المبلغ عنها في الفي البـالغين حتى الآن. الكلمات المفتاحية: التهاب الجلد حول الفم؛ التهاب الجلد؛ أورام حبيبية روماتزمية؛ تقرير حالة؛ عمان.

G RANULOMATOUS PERIORIFICIAL DERMATITIS (GPD), also known as childhood granulomatous periorificial dermatitis (CGPD), is an uncommon, benign inflammatory skin disease that affects primarily dark-skinned prepubertal children; few cases have been reported in adults. ${ }^{1-5}$ It is characterised by a monomorphic, skin-coloured to yellow-brown or red papular eruption around the mouth, nose and eyes that usually heals with no scarring. However, extra-facial lesions have been reported. ${ }^{6}$ GPD shares many similarities with granulomatous rosacea (GR) and cutaneous sarcoidosis. Some authors consider it a variant of GR, while others suggest that it may be a variant of sarcoidosis. ${ }^{7,8}$ This case report describes a rare case of GPD in an adult with sarcoidlike histology that was successfully treated with oral doxycycline and topical metronidazole. In addition, this report discusses controversies and distinguishing features of GPD from GR and sarcoidosis as well as a review of literature of all reported cases of GPD in adults.

\section{Case report}

A 36-year-old Omani male patient presented to the Dermatology Clinic at Bahla Polyclinic, Bahla, Oman, in 2018 with a papular eruption over his face for the previous six months. He reported no itching, burning sensation or facial redness. He had no known comorbidities and denied a history of fever, shortness of breath or other systemic complaints. In addition, he denied having used any topical or oral medications prior to the eruption. There was no recent history of travel and no abnormal environmental exposure. He was prescribed topical mometasone cream for two months and tacrolimus (0.1\%) ointment for three months with partial response and recurrence once the treatment was discontinued.

Following the reoccurrence of the papular eruption, examination showed monomorphic scaly erythematous papules localised to the perioral, paranasal and periorbital areas of the face [Figure 1]. The vermilion border 

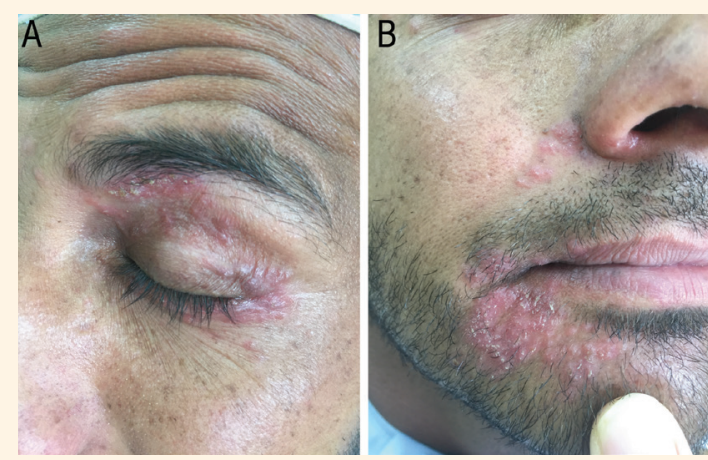

Figure 1: Photographs of the face of a 36-year-old male showing monomorphic erythematous scaly papules localised to (A) periorbital, (B) paranasal and perioral areas with involvement of vermilion border.

was involved. There was no facial erythema or telangiectasia. There were no other skin lesions and other orifices were not involved. The rest of the physical examination was unremarkable. The differential diagnoses included periorificial dermatitis, GR, cutaneous sarcoidosis and lupus miliaris disseminatus faciei (LMDF).

Laboratory investigations, including angiotensin converting enzyme (ACE) levels, were normal. The chest $\mathrm{X}$-ray was also normal. A punch biopsy was taken from the area with erythematous papules and sent for histological investigation.

Histopathological examination of an erythematous papule showed non-caseating naked granulomas containing histiocytes, multinucleated giant cell of Langhans type and focally surrounded lymphocytes [Figure 2]. Periadnexal and perivascular lymphocytic infiltrate was also present. Stains for fungi (i.e. periodic acid-Schiff) and acid-fast bacilli (i.e. Ziehl-Neelsen and Wade-Fite) were negative.

As a result of the clinical and histopathological findings, the patient was diagnosed with GPD. The patient was treated with oral doxycycline (100 mg) once daily and topical metronidazole cream twice daily. He showed marked improvement after six weeks with complete resolution of the lesions without scarring after 12 weeks, after which treatments were stopped [Figure 3]. He had no recurrence on follow-up visits after three and six months.

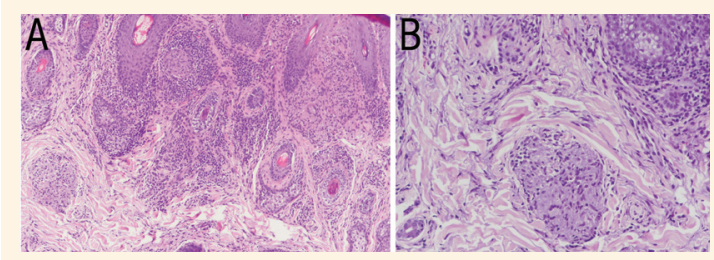

Figure 2: Haematoxylin and eosin stains at (A) x10 magnification showing non-caseating granulomatous inflammation with some naked granulomas and (B) at $\times 40 \mathrm{mag}-$ nification showing surrounding lymphocytic infiltrate.

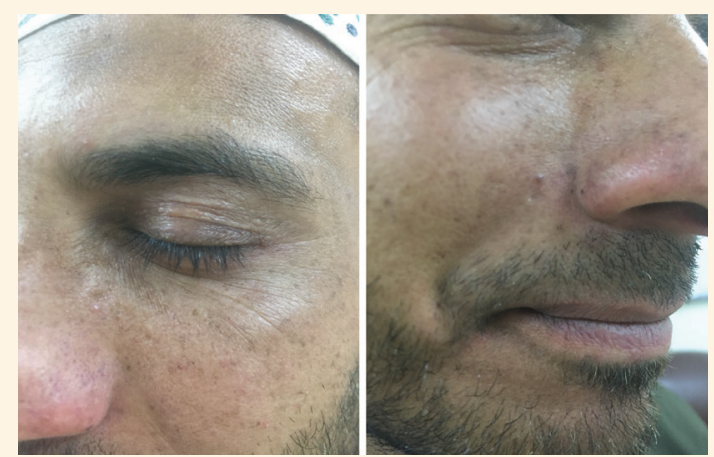

Figure 3: Photographs of the face of a 36-year-old male showing complete resolution after 12 weeks of treatment with oral doxycycline and metronidazole cream.

The patient gave consent for his images and clinical information to be reported in a journal. The authors explained that while the patient's name would not be published, complete anonymity could not be guaranteed.

\section{Discussion}

GPD is a well-recognised entity that affects commonly dark-skinned prepubertal children. While topical steroids are considered to be the most important and frequently reported pathogenic factor, other reported factors include cosmetic products, physical factors and microorganisms. ${ }^{1,8-11}$

GPD is a controversial disease as it shares many similarities with other granulomatous disorders such as GR and cutaneous sarcoidosis. GDP is distinguished from cutaneous sarcoidosis by the absence of systemic involvement and a self-limiting nature. Antony et al. reported a case of GPD that could be a variant of sarcoidosis with raised ACE levels and a chronic nature. ${ }^{8}$ GR usually shows similar histology to GPD but it mainly affects the central face and may show classic signs of telangiectasia, oedema and erythema. ${ }^{7}$ LMDF is distinguishable from GPD as it has a tendency to affect periorbital areas only, a presence of caseation on histology and resolution with scarring. Misago et al. reported a case of CGPD with similar features to LMDF suggesting that the term 'facial idiopathic granulomas with regressive evolution' should include both CGPD and LMDF. ${ }^{12}$ Since GPD sometimes presents with eczematous features, seborrheic dermatitis is also an accepted differential diagnosis, but the latter usually involves other areas such as the eyebrows and scalp with a dramatic response to topical steroids and different histologic features without granulomas. Dermatoscopy may show additional features that aid in diagnosis. ${ }^{13}$ Table 1 summarises the differential diagnoses with 
Table 1: Differential diagnosis of granulomatous papules on the face $\mathrm{e}^{11,13-17}$

\begin{tabular}{|c|c|c|c|c|c|}
\hline Disease & $\begin{array}{l}\text { Typical patient } \\
\text { characteristics }\end{array}$ & Clinical features & $\begin{array}{l}\text { Main dermoscopic } \\
\text { features }\end{array}$ & $\begin{array}{l}\text { Histopathological } \\
\text { findings }\end{array}$ & Prognosis \\
\hline GPD & $\begin{array}{l}\text { - Prepubertal } \\
\text { children } \\
\text { - Rarely seen in } \\
\text { adults }\end{array}$ & $\begin{array}{l}\text { - Monomorphic, skin-coloured to yellow- } \\
\text { brown or red papules confined to the } \\
\text { periorificial areas of the face }\end{array}$ & - Not described & $\begin{array}{l}\text { - Dermal non- } \\
\text { caseating granulomas }\end{array}$ & $\begin{array}{l}\text { - Spontaneous } \\
\text { resolution without } \\
\text { scarring }\end{array}$ \\
\hline GR & $\begin{array}{l}\text { - Middle-aged } \\
\text { women }\end{array}$ & $\begin{array}{l}\text { - Yellow-brown or pink papules on the } \\
\text { cheeks, periorbital or perioral skin } \\
\text { - Blushing, erythema or telangiectasia, } \\
\text { may be seen }\end{array}$ & $\begin{array}{l}\text { - Linear reddish or } \\
\text { purple vessels arranged } \\
\text { in a polygonal network } \\
\text { (vascular polygons) }\end{array}$ & $\begin{array}{l}\text { - Epithelioid } \\
\text { granulomas adjacent to } \\
\text { hair follicles } \\
\text { - Caseation in } 10 \% \text { of } \\
\text { the cases }\end{array}$ & - Chronic nature \\
\hline $\begin{array}{l}\text { Cutaneous } \\
\text { sarcoidosis }\end{array}$ & $\begin{array}{l}\text { - Any age and } \\
\text { gender }\end{array}$ & $\begin{array}{l}\text { - Non-inflammatory facial papules and } \\
\text { nodules with systemic symptoms such } \\
\text { as fatigue, weight loss, joint pain and } \\
\text { pulmonary symptoms }\end{array}$ & $\begin{array}{l}\text { - Structure-less, orangish } \\
\text { areas and well-focused } \\
\text { linear or branching } \\
\text { vessels }\end{array}$ & $\begin{array}{l}\text { - Naked, non-caseating } \\
\text { granulomatous } \\
\text { infiltration }\end{array}$ & - Chronic nature \\
\hline
\end{tabular}

$G P D=$ granulomatous periorificial dermatitis; $G R=$ granulomatous rosacea $[M D F=$ lupus miliaris disseminatus faciei .

Table 2: Summary of reported cases of granulomatous periorificial dermatitis in adults ${ }^{1-5}$

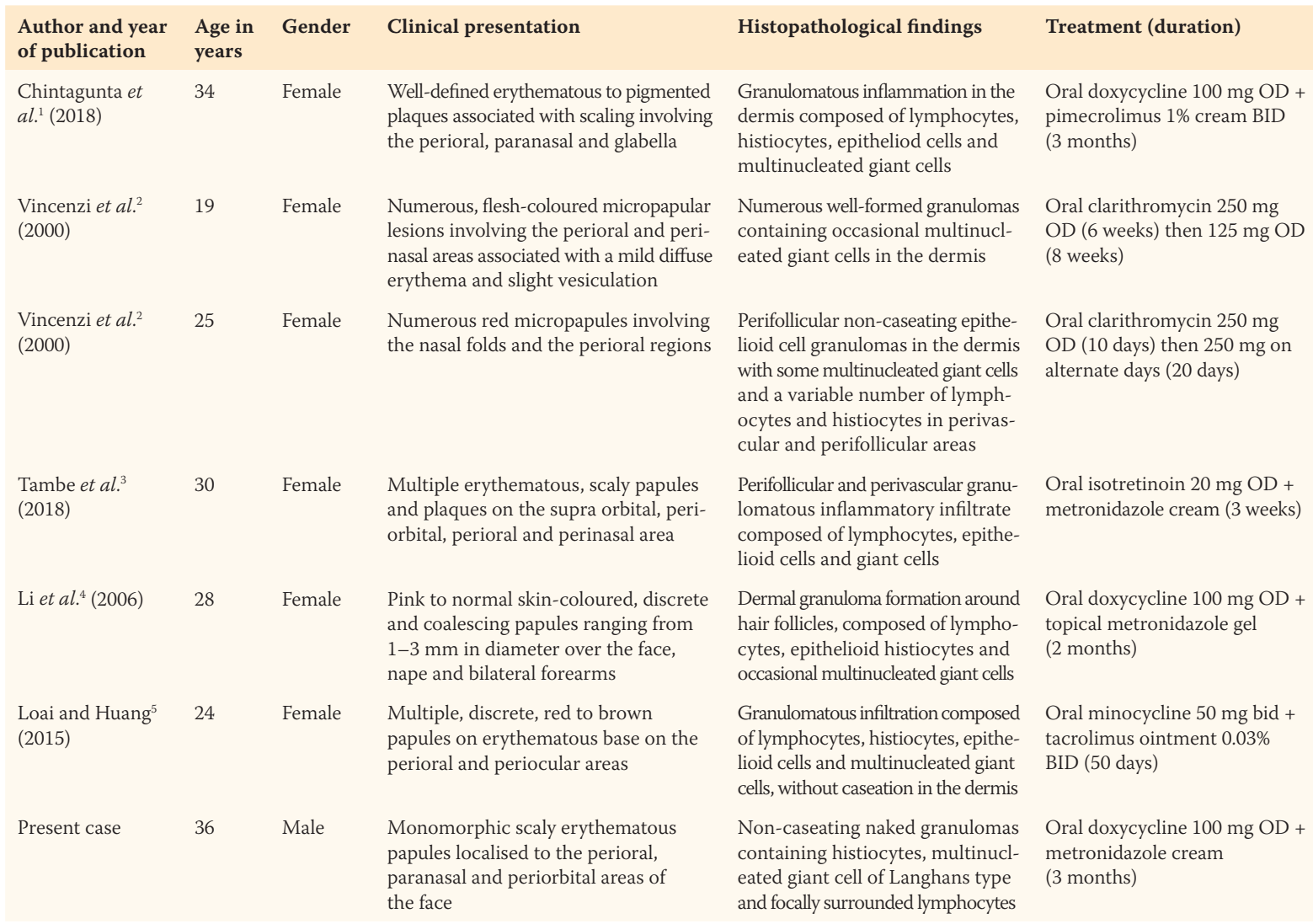

clinical and dermoscopic features of granulomatous papules on the face.

GPD has a self-limiting nature, therefore treatment is not necessary. However, many topical and systemic treatments have been reported to hasten clearance. ${ }^{1,2,6,7,11,18}$ Topical treatments include metronidazole, erythromycin or pimecrolimus. ${ }^{1,6,11}$ Systemic treatments mainly include tetracycline antibiotics such as tetracycline and doxycycline; oral erythromycin and clarithromycin are also effective. ${ }^{2,7,18}$
To date, there are a total of six reported cases of GPD in adults [Table 2].1-5 The present case is the only case in a male. In two cases, the lesions were erythematous plaques and the remainder had erythematous papules as in the present case. All cases showed dermal noncaseating granulomas upon histopathological examination. One case was treated with oral isotretinoin while the others were treated with oral antibiotics. All cases showed complete resolution without recurrence. 


\section{Conclusion}

GPD is a well-recognised entity that may affect adults and should be differentiated from GR, cutaneous sarcoidosis and other granulomatous disorders of the face by clinicopathological correlation to minimise systemic treatment use.

\section{References}

1. Chintagunta S, Manchala S, Arakkal G. Granulomatous periorificial dermatitis in an adult: A rare case report. J Dr NTR Univ Health Sci 2018; 7:143-6. https://doi.org/10.4103/22778632.233845 .

2. Vincenzi C, Parente G, Tosti A. Perioral granulomatous dermatitis: Two cases treated with clarithromycin. J Dermatolog Treat 2000; 11:57-61. https://doi.org/10.1080/09546630050517702.

3. Tambe S, Jerajani H, Pund P. Granulomatous periorificial dermatitis effectively managed with oral isotretinoin. Indian Dermatol Online J 2018; 9:68-70. https://doi.org/10.4103/idoj. IDOJ_129_17.

4. Li YW, Chuan MT, Hu SL. Granulomatous periorificial dermatitis in a young woman. Dermatol Sinica 2006; 24:38-41. https://doi.org/10.29784/DS.200603.0006.

5. Loai S, Huang C. Childhood granulomatous perioral dermatitis with good responses to minocycline and topical tacrolimus, extraordinary significance. Austin J Dermatol 2015; 2:1034.

6. Urbatsch AJ, Frieden I, Williams ML, Elewski BE, Mancini AJ Paller AS. Extrafacial and generalized granulomatous periorificial dermatitis. Arch Dermatol 2002; 138:1354-8. https://doi.org/10.1 001/archderm.138.10.1354.

7. Lucas CR, Korman NJ, Gilliam AC. Granulomatous periorificial dermatitis: A variant of granulomatous rosacea in children? J Cutan Med Surg 2009; 13:115-18. https://doi.org/10.2310/77 50.2008.07088
8. Antony FC, Buckley DA, Russell-Jones R. Childhood granulomatous periorificial dermatitis in an Asian girl--A variant of sarcoid? Clin Exp Dermatol 2002; 27:275-6. https://doi.org/10.1 046/j.1365-2230.2002.01019.x.

9. Zalaudek I, Di Stefani A, Ferrara G, Argenziano G. Childhood granulomatous periorificial dermatitis: A controversial disease. J Dtsch Dermatol Ges 2005; 3:252-5. https://doi.org/10.1111/ j.1610-0387.2005.05009.x.

10. Hatanaka M, Kanekura T. Case of childhood granulomatous periorificial dermatitis. J Dermatol 2018; 45:e256-7. https://doi.org/10.1111/1346-8138.14296.

11. Lee GL, Zirwas MJ. Granulomatous rosacea and periorificial dermatitis: Controversies and review of management and treatment. Dermatol Clin 2015; 33:447-55. https://doi.org/10.1016/j. det.2015.03.009

12. Misago N, Nakafusa J, Narisawa Y. Childhood granulomatous periorificial dermatitis: Lupus miliaris disseminatus faciei in children? J Eur Acad Dermatol Venereol 2005; 19:470-3. https://doi.org/10.1111/j.1468-3083.2004.01178.x.

13. Errichetti E, Stinco G. Dermatoscopy of granulomatous disorders. Dermatol Clin 2018; 36:369-75. https://doi.org/10.1016/j.det.2 018.05.004.

14. Khokhar O, Khachemoune A. A case of granulomatous rosacea: Sorting granulomatous rosacea from other granulomatous diseases that affect the face. Dermatol Online J 2004; 10:6.

15. Elder D, Elenitsas R, Johnson BL, Murphy GF. Lever's Histopathology of the Skin. 9th ed. Philadelphia, Pennsylvania, USA: Lippincott Williams and Wilkins, 2005. P. 469.

16. Ayhan E, Alabalik U, Avci Y. Dermoscopic evaluation of two patients with lupus miliaris disseminatus faciei. Clin Exp Dermatol 2014; 39:500-2. https://doi.org/10.1111/ced.12331.

17. Toda-Brito H, Aranha JMP, Tavares ES. Lupus miliaris disseminatus faciei. An Bras Dermatol 2017; 92:851-3. https://doi.org/10.1 590/abd1806-4841.20174534

18. Choi YL, Lee KJ, Cho HJ, Kim WS, Lee JH, Yang JM, et al. Case of childhood granulomatous periorificial dermatitis in a Korean boy treated by oral erythromycin. J Dermatol 2006; 33:806-8. https://doi.org/10.1111/j.1346-8138.2006.00183.x. 